inOedia $\quad \begin{aligned} & \text { InMedia } \\ & \text { The French Journal of Media Studies }\end{aligned}$

$1 \mid 2012$

Global Film and Television Industries Today

\title{
The Impact of Runaway Productions on Hollywood Labor Organizations
}

Daniel Peltzman

\section{OpenEdition}

1 Journals

Electronic version

URL: http://journals.openedition.org/inmedia/123

DOI: 10.4000/inmedia.123

ISSN: 2259-4728

Publisher

Center for Research on the English-Speaking World (CREW)

Electronic reference

Daniel Peltzman, «The Impact of Runaway Productions on Hollywood Labor Organizations », InMedia [Online], 1 | 2012, Online since 23 March 2012, connection on 08 September 2020. URL : http:// journals.openedition.org/inmedia/123 ; DOI : https://doi.org/10.4000/inmedia.123

This text was automatically generated on 8 September 2020

(C) InMedia 


\title{
The Impact of Runaway Productions on Hollywood Labor Organizations
}

\author{
Daniel Peltzman
}

1 In line with relocations which have restructured US manufacturing, the Hollywood motion picture industry has suffered from the impact of runaway productions. By definition, a runaway production is a movie that will be exploited in the United States but whose shooting has taken place outside Hollywood or abroad. There are two basic types of runaway productions: creative runaway productions are justified by the artistic choice to use a natural setting to enhance the plot; economic runaway productions on the other hand, by far the most common, are justified by lower production costs than those practised in Californian studios. There is also a political dimension which may infringe upon global trade: foreign government can offer incentives in the form of subsidies or substantial tax credits.

2 The number of economic runaway productions has soared thereby creating an immediate impact on Hollywood labor organizations. This study focuses on Hollywood's oldest labor union: the International Alliance of Stage and Theatrical Employees (IATSE). First composed of stage hands and projectionists, IATSE members today include craftsmen and a wide variety of technicians. ${ }^{1}$ In 1936, IATSE was the first Hollywood union to obtain the union shop, thereby making union membership a prerequisite of employment. Affiliated with the AFL-CIO the IATSE has always practiced a collective bargaining policy, regularly negotiating contracts with the producers. This has contributed to establishing the bureaucratic and hierarchical structure within which the union now operates-a structure which largely excludes the rank and file from the decision-making process. ${ }^{2}$ The situation for talent guilds such as the Screen Actors' Guild, the Screen Directors' Guild and the Writers' Guild of America is less problematic in so far as the impact of economic runaway productions is less significant than for IATSE members. For obvious reasons, American actors, directors, and writers can work on a foreign project whereas technicians and craftsmen crews are generally drawn from the local workforce. And while runaway productions certainly create problems for guilds' members, for their IATSE counterparts rising unemployment is 
inevitable. A screen writer can easily work for a runaway production from his own home; this alternative is clearly impossible for technicians and craftsmen employed in a Hollywood studio.

3 The historical structure of Hollywood labor organizations such as the IATSE further complicates these challenges. After many years of fierce struggle their members obtained the right to collective bargaining and union shop agreements with Hollywood producers. ${ }^{3}$ For decades, the Los Angeles region offered US film producers the best economic conditions and a plethora of natural landscape settings. This status gradually evolved over time as the state of New York, while never matching Hollywood, imposed itself as an important production center in its own right. Today, in the United States alone, more than thirty states offer American motion picture companies tax credits, further reinforcing the runaway production process. The issue is further complicated by the fact that labor law varies significantly from one state to another and hence its impact on IATSE members. The problem is therefore twofold as runaway productions function on both international and domestic levels.

4 This all comes down to a number of essential issues. Do runaway productions have the same repercussions on workers' rights when they take place in Canada or Utah? How have unions reacted to the problem? By way of response, this paper will start with a brief historical overview of economic runaway productions before focusing in greater detail on current issues and analyzing their effects on Hollywood labor organizations.

\section{Historical Background}

5 Economic runaway productions are by no means a new phenomenon. Such productions have existed to a greater or lesser degree depending on the historical context, with their number increasing significantly from the 1950s onwards. But producing offshore may often have created at least as many problems as it aimed to solve. The movie adaptation of Lew Wallace's Ben Hur provides a noteworthy example from as early as 1925. The film was produced first by Samuel Goldwyn, then by his new company, the soon renowned Metro Goldwyn Mayer. Fred Niblo was named director and the decision was made to shoot the film in Italy for artistic reasons. This second adaptation of Wallace's novel represented a capital investment hitherto unheard of. Yet the budget notwithstanding, the shooting turned out to be an unmitigated disaster. During the famous naval battle scene, the galleys caught fire: many extras, their costumes ablaze, had to dive into the water. Unfortunately, some of them were unable to swim and a dozen of them perished. Adding to this tragic event, technical constraints forced the operation back to the United States in Hollywood, where new sets had to be built. Even if the audience was impressed by the chariot race, the company never recouped its colossal expenses. In fact, the movie would become the epitome of how unprepared the company had been for the artistic, financial and technical challenges of such runaway productions. ${ }^{4}$ Though Italy already boasted a powerful motion picture industry at that time, Hollywood producers would henceforth be reluctant to relocate their production abroad for fear of uncertain costs. International runaway productions would be extremely rare in the decades to come.

6 By the mid-1950s, however, the number of economic runaway productions rose so dramatically that Hollywood labor organizations began to heed, all the more so as the period itself was particularly trying for the industry. While the country enjoyed 
unprecedented prosperity, Hollywood was facing the worst crisis of its history. A number of reasons help to explain this downturn. First, the famous Paramount case dissolved the Hollywood trust forcing the producers to sell the vast majority of their movie theaters. ${ }^{5}$ Second, middle-class Americans, lured by newly built suburbs, were progressively leaving inner cities where movie theaters were chiefly situated. Finally, the advent of television resulted in a dramatic drop of movie attendance. This new vulnerability of studios helps explain the sudden increase in economic runaway productions. Thus, while in 1946, only $19 \%$ of all films in the United States were foreign productions, by 1956 this figure had more than doubled. That year, $43 \%$ of all American-produced films had been made abroad. In 1966, the figure was $65 \%$ and $70 \%$ a year later. ${ }^{6}$

7 In 1957 the Hollywood American of Labor Council, composed of all the Hollywood industry locals affiliated with the American Federation of Labor (AFL), asked labor historian Irving Bernstein to study the situation of the labor force in Hollywood studios. The AFL was concerned about rising unemployment rates and the vulnerability of unionized workers. Bernstein provided a clear and complete report, highlighting the link between the unemployment rate at home and the frequency of runaway productions. It became patently obvious that studios were hardly hiring any new workers. ${ }^{7}$

8 Runaway productions also contributed to the diversification of Hollywood studios abroad. In 1956, Warner Brothers owned 37\% of the voting stock of Associated British Picture Corp. Ltd., which operated studio, laboratory and distribution network facilities on the other side of the Atlantic. At this time, Twentieth Century-Fox was investing in movie production in Europe and Africa. Diversification had obvious consequences on employment of IATSE members. For example, when Warner was producing a film in England, IATSE laboratory technicians, who developed films, would find themselves unemployed. Likewise, IATSE carpenters and electricians employed on Hollywood sets would not be sent on location in Europe.

9 Italy was among Hollywood's favorite offshore locations for a number of reasons. After his visit in 1956 to study the country's motion picture industry, producer Dore Schary reported back in the US: "I visited the Cinecitta studios, a thoroughly modern and complete lot, but the only two pictures shooting at the time were David Selznick's production of Farewell to Arms and Joe Mankiewicz's production The Quiet American." With evident bitterness Bernstein questioned rhetorically where the American motion picture industry was. In Hollywood or in Rome? The labor historian explained the phenomenon by underlining the appeal of tax credits that many European countries were offering at the time. More recently, the number of countries hosting Hollywood productions has continued to grow for the very same reasons-with the lower standard of living and labor costs also contributing to this trend.

\section{Economic Runaway Productions Today}

10 In 1970, AFL leaders publicly denounced the production of American films abroad, which literally left thousands of unemployed at home. ${ }^{9}$ According to union leaders, the trend was accelerating and this has since proven to be the case. Several surveys illustrate this surge. Between 1993 and 2001, US production budgets decreased by 17\%. During the same period, costs in Canada increased 144\%. In 1998, $28 \%$ of all the movies 
shown in the United States were runaway productions representing a direct economic loss of over $\$ 2.8$ billion in wages. With additional losses linked to derivative activities such as housing, transportation and catering, the figure rose to $\$ 10.3$ billion. ${ }^{10}$ In California alone, 182 movies were produced in 2004 while just four years earlier Hollywood studios had produced 212. In 2003, however, their number had plunged to 151.

11 There are many causes for the spectacular increase in runaway productions. First the quest for profit coupled with the advent of neoliberalism that encourages free trade has tended towards worldwide integration of economic activity. Even in Europe, the comparatively low standard of living more than counterbalances the strength of the euro against the dollar. It is thus hardly surprising that Hollywood studios should have succeeded in making substantial profits thanks to runaway productions. If making pictures abroad is more profitable, producers will not hesitate to do so. This should be understood within the context of soaring production costs. Between 1990 and 2000, average price costs rose from $\$ 26.8$ million to $\$ 51.5$ million. One obvious conclusion is that the labor costs have to be taken into account. ${ }^{11}$

12 Secondly, technical innovations are also partly responsible. In the late 1980s, it was extremely expensive to move a crew from Hollywood to a foreign country. Today, however, a film can be shot abroad and rushes (the first prints made of a movie after shooting) immediately transmitted to California, where, for instance, the film is then edited. Countries such as Britain, New Zealand, and Canada have greatly improved their technical facilities and offer trained local labor forces in situ. In the United States, states such as New York, Louisiana, and New Mexico have followed suit. It has been estimated that across the US, 20,000 of the total of 270,000 industry jobs were lost in 1998 alone due to runaway productions..$^{12}$ IATSE members in Hollywood are among those who have lost their jobs - most notably craftsmen such as carpenters, prop men, decorators and many others whose tasks can be carried out on the production set. ${ }^{13}$

13 Thirdly, most of the Hollywood studios have been offered tax relief by other countries or states mostly in the form of tax credits or deductions. In the US alone, Arizona offers a $20 \%$ tax credit for a $\$ 3$ million movie conditioned upon the number of state workers employed. Respectively, 32 states have passed laws offering such tax credits. ${ }^{14}$ The situation is comparable in other countries. The South African government offers a $15 \%$ tax credit on profits if at least half the movie is shot there. Production costs are therefore $25 \%$ lower. ${ }^{15}$

\section{The Impact on Hollywood Trade Unions}

Before analyzing the impact of runaway productions upon trade unions, some data about motion picture industry employment should be provided. In 2002, the Motion Picture Association of America (MPAA) organized a census covering the United States and Hollywood. Among other findings, the census detailed the wages paid by the MPAA. In the United States, 353,076 people were employed in the industry including 245,900 in Hollywood alone. Film workers collectively earned $\$ 21.2$ billion nationwide, $\$ 17.2$ billion of it in Hollywood. In other words, Hollywood is still the heart of the industry. Yet this apparent asset for California also has its drawbacks, for it is the state that has consequently been the hardest hit by runaway productions. ${ }^{16}$ 
15 When a studio relocates its production outside California many workers find themselves forced to leave the state or the country for fear of irrevocably losing their jobs. Job loss figures speak for themselves: between 1988 and 1998, the number of fulltime film industry jobs plummeted from 76,000 to $12,000 .{ }^{17}$ The consequences are serious since unemployed workers are generally deprived of pension benefits and see their health care removed.

16 Also, when a studio budgets a movie, it must consider both "above the line" costs that include actors and directors and 'below the line' costs of supporting actors, makeup artists, craftsmen, and others. It is clearly the latter who are more vulnerable to employment flexibility brought about by runaway productions as producers take advantage of cheap labor costs outside Hollywood. ${ }^{18}$ This phenomenon has become increasingly commonplace even if, when the runaway production is in the United States, many IATSE workers are given the option of following the crew or risk losing their jobs. Following the crew means leaving Hollywood, sometimes for months. ${ }^{19}$

\section{The Unions' Response}

17 For most IATSE officials the only solution is to obtain the intervention of Congress or state legislatures. This is not new. In 1949, Ronald Reagan, then president of the Screen Actors' Guild and actor Kenneth Thompson with IATSE president Richard Walsh, met President Truman to inform him about the problems raised by runaway productions. Later, as Governor of California, Reagan would advocate a laissez-faire policy based on the idea that governments should not interfere, yet he asked the federal government to improve the situation of Hollywood workers facing runaway productions..$^{20}$

18 Today, the IATSE represents a powerful lobby that continues to push for political intervention. The California Coalition for Entertainment Jobs, a coalition of Hollywood labor unions and guilds, has recently put pressure on the legislature to obtain jobsaving tax credits and wage-based tax incentives. ${ }^{21}$ IATSE lobbyists have been everpresent in congressional hearings and endeavored to convince California state elected officials to pass legislation to this effect. Edward Brown, business agent of IATSE Local 44 (prop men), has testified several times before the California legislature. In 2007 he openly favored the voting of tax credits:

Incentives absolutely could be helpful.... We're really being affected by a loss of jobs that traditionally have been located here in Southern California but which have been exported to other states.... Our members are forced to chase jobs being shifted to other states.... Other states are aggressively pursuing our tax dollars by going after our productions. In effect, they're stealing our money. ${ }^{22}$

Meanwhile, some IATSE locals have launched campaigns against foreign countries that grant substantial tax credits. How effective is such lobbying on politicians? On the one hand, union solidarity between the Screen Actors' Guild and IATSE leadership succeeded in the New York state Congress passing a 2006 law that increased tax credits for productions shot in the city:

21 The new legislation significantly increases the state $10 \%$ credit from $\$ 25$ million to $\$ 60$ million; allows New York City to more than double its $5 \%$ tax credit from $\$ 12.5$ million per year to $\$ 30$ million per year for production shot within the city.... SAG lobbied aggressively.... The guild worked in concert with IATSE. ${ }^{23}$ 

Hollywood. Foreign motion picture companies have at their disposal facilities that once made Hollywood world capital of the movie industry. Also, globalization that keeps on crossing more borders and the World Trade Organization and its neoliberal approach are set to encourage movie production outside Hollywood. It will be up to Hollywood labor unions to cope with this problem by themselves.

\section{BIBLIOGRAPHY}

Baker Roberts, Osborn. The International Alliance of Theatrical Stage Employees and Moving Picture Operators in the United States and Canada. Lawrence: University of Kansas Press, 1933.

Berstein, Irving. Hollywood at the Crossroads: An Economic Study of the Motion Picture Industry. Hollywood: Hollywood AFL Film Council, December 1957.

Center for Entertainment and Data Research. The Migration of Feature Film Production From the US to Canada and Beyond, Year 2001 Production Report. Los Angeles, 2002.

Conant, Michael. Antitrust in the Motion Picture Industry: Economic and Legal Analysis. Berkeley: University of California Press, 1960. 
Diorio, Al. “Politicians Focus On Runaway Production." Hollywood Reporter, June 25, 2007. http:// democrats.assembly.ca.gov/members/filmproduction/articles/20070625Art001.htm <accessed November 5, 2009>.

Free Library, AB 2747 Was Voted One Dissenting Vote. http://www.Thefreelibrary.com/ $\mathrm{AB}+$ Passes+California+Stae+Assembly\%3B+Anti-Runaway+Production < accessed on November 5 , 2009>.

Freeman, Gregory, Kyser, Jack, Sidhu, Nancy, Huang, George, Montoya, Michael. What is the Cost of Runaway Production? Jobs, Wages, Economic Output and State Tax Revenue at Risk When Motion Picture Production Leaves California. Los Angeles: Los Angeles County Economic Development Corporation, August 2005.

Hearings Before the General Subcommittee on Labor of the Committee on Labor and Education, House of Representatives, Ninety Second Congress, First Session on Unemployment Problems in American Film Industry, Hearings Held at Los Angeles, California, October 29 and 30, 1971. Printing Government Office.

Lovell, Hugh, Carter, Tasile. Collective Bargaining in the Motion Picture Industry. Institute of Industrial Relations, Berkeley: University of California Press, 1955.

McDougal, Dennis. The Last Mogul: Lew Wasserman, MCA, and the Hidden History of Hollywood. New York: Crown Publishers, 1998.

Monitor Company. The Economic Impact of U.S Film and Television Runaway Production. Cambridge, June 1999.

Perry, Louis B., Perry, Richard S. A History of the Los Angeles Labor Movement, 1911-1941. Berkeley: University of California Press, 1963.

Ross, Murray. Stars and Strikes: Unionization of Hollywood. New York: Columbia University Press, 1941.

Schulberg, Budd. Moving Picture: Memoires of a Hollywood Prince. London: Penguin Books, 1984.

Screen Actors' Guild. SAG Worked with Coalition of Unions on Tax Incentive Bill worth $\$ 400$ million, April 27, 2006, http://www.sag.org/content/guild-victory-big-apple-takes-another-bite-out-ofrunaway-production <accessed on November 5, 2009>.

Ulich, Pamela Conley, Simmons, Lance. "Motion Picture Production: To Run or Stay Made in the USA.” Loyola of Los Angeles Entertainment Law Review, Vol. 21:357, 2001.

\section{NOTES}

1. IATSE locals include: laboratory technicians, make-up artists, scenic artists, stagehands, property craftsmen, grips, studio carpenters, costumers, sound technicians, etc.

2. Hugh Lovell and Tasile Carter, Collective Bargaining in the Motion Picture Industry (Institute of Industrial Relations, Berkeley: University of California Press, 1955) 18.

3. Roberts Osborn Baker, The International Alliance of Theatrical Stage Employees and Moving Picture Operators in the United States and Canada (Lawrence: University of Kansas Press, 1933).

4. Budd Schulberg, Moving Picture: Memoires of a Hollywood Prince (1981, London: Penguin Books, 1984) 206-7.

5. Michael Conant, Antitrust in the Motion Picture Industry: Economic and Legal Analysis (Berkeley: University of California Press, 1960) 107-153. 
6. Hearings Before the General Subcommittee on Labor of the Committee on Labor and Education, House of Representatives, Ninety Second Congress, First Session on Unemployment Problems in American Film Industry, Hearings Held at Los Angeles, California, October 29 and 30, 1971, Printing Government Office, 37.

7. Irving Bernstein, Hollywood at the Crossroads: An Economic Study of the Motion Picture Industry, Hollywood, Hollywood AFL Film Council, December 1957, 30-7.

8. Irving Bernstein, Hollywood at the Crossroads: An Economic Study of the Motion Picture Industry, Hollywood, Hollywood AFL Film Council, December 1957, 25-6, 45.

9. Hearings Before the General Subcommittee on Labor of the Committee on Labor and Education, House of Representatives, Ninety Second Congress, First Session on Unemployment Problems in American Film Industry, Hearings Held at Los Angeles, California, October 29 and 30, 1971, Printing Government Office, 37, 44.

10. Monitor Company, The Economic Impact of U.S. Film and Television Runaway Production, Cambridge, June 1999, 2-3.

11. Pamela Conley Ulich and Lance Simmons, "Motion Picture Production: To Run or Stay Made in the U.S.A," Loyola of Los Angeles Entertainment Law Review, 21:357 (2001): 358.

12. Pamela Conley Ulich and Lance Simmons, "Motion Picture Production: To Run or Stay Made in the U.S.A." Loyola of Los Angeles Entertainment Law Review, 21:357 (2001): 367.

13. Gregory Freeman et al., What is the Cost of Runaway Production? Jobs, Wages, Economic Output and State Tax Revenue at Risk When Motion Picture Production Leaves California, Los Angeles, Los Angeles County Economic Development Corporation, August 2005, 17.

14. Al Diorio, "Politicians Focus on Runaway Production," Hollywood Reporter, June 25, 2007, http://democrats.assembly.ca.gov/members/filmproduction/articles/20070625Art001.htm.

$<$ accessed on November 5, 2009, 1>.

15. Monitor Company, The Economic Impact of U.S Film and Television Runaway Production, Cambridge, June 1999, 4.

16. Gregory Freeman et al., What is the Cost of Runaway Production? Jobs, Wages, Economic Output and State Tax Revenue at Risk When Motion Picture Production Leaves California, Los Angeles, Los Angeles County Economic Development Corporation, August 2005, 2.

17. Monitor Company, The Economic Impact of U.S Film and Television Runaway Production, Cambridge, June 1999, 15-6.

18. Monitor Company, The Economic Impact of U.S Film and Television Runaway Production, Cambridge, June 1999, 18-8, 28.

19. Al Diorio, "Politicians Focus On Runaway Production," Hollywood Reporter, June 25, 2007, http://democrats.assembly.ca.gov/members/filmproduction/articles/20070625Art001.htm.

$<$ accessed November 5, 2009, 1>.

20. Hearings Before the General Subcommittee on Labor of the Committee on Labor and Education, House of Representatives, Ninety Second Congress, First Session on Unemployment Problems in American Film Industry, Hearings Held at Los Angeles, California, October 29 and 30, 1971, Printing Government Office, 53.

21. Free Library, $A B 2747$ Was Voted One Dissenting Vote, http://www.Thefreelibrary.com/ $\mathrm{AB}+$ Passes + California+Stae+Assembly\%3B+Anti-Runaway+Production. <accessed on November 5 , 2009>.

22. Al Diorio, "Politicians Focus On Runaway Production," Hollywood Reporter, June 25, 2007, http://democrats.assembly.ca.gov/members/filmproduction/articles/20070625Art001.htm. $<$ accessed on November 5, 2009>.

23. Screen Actors' Guild, SAG Worked with Coalition of Unions on Tax Incentive Bill worth $\$ 400$ million, April 27, 2006, http://www.sag.org/content/guild-victory-big-apple-takes-another-bite-out-ofrunaway-production. <accessed on November 5, 2009>. 
24. Dennis McDougal, The Last Mogul: Lew Wasserman, MCA, and the Hidden History of Hollywood (New York: Crown Publishers, 1998) 263.

\section{ABSTRACTS}

This study tries to show the impact of runaway productions on Hollywood labor unions. In the context of globalization, and also of US federalism used to lower labor standards, the unions' response towards the producers has generally been weak despite some successes in recent years, notably of the screen writers in 2007. Among all the unionized in the motion picture industry, members of the International Alliance of Theatrical Stage Employees (IATSE) and members of the Screen Actors' Guild are some of the most vulnerable.

\section{INDEX}

Keywords: Hollywood, motion picture industry, Hollywood labor organizations, talent guilds, runaway productions, International Alliance of Theatrical and Stage Employees (IATSE), Motion Picture Association of America (MPPA)

\section{AUTHOR}

\section{DANIEL PELTZMAN}

Daniel Peltzman is an Associate Professor in American Studies at the Université de FrancheComté, Besançon, France. His research area is Hollywood trade unions, as well as McCarthyism. Université de Franche-Comté 